\title{
Adsorption and coagulation in wastewater treatment - Review
}

\author{
HADID SUKMANA $^{1 *}$ (D), NAOUFAL BELLAHSEN ${ }^{1}$, \\ FERNANDA PANTOJA ${ }^{1}$ and CECILIA HODUR ${ }^{2}$
}

${ }^{1}$ Doctoral School of Environmental Sciences, University of Szeged, H-6720 Szeged, Hungary

${ }^{2}$ Department of Biosystems Engineering, University of Szeged, H-6725 Szeged, Hungary

\section{REVIEW PAPER}

Received: September 14, 2021 • Accepted: October 24, 2021

Published online: November 19, 2021

(c) 2021 The Author(s)

\begin{abstract}
Wastewater issues became a complex challenge in the world. There are several methods in wastewater treatment, such as chemical, physical, biological, and the combination of each method. However, each process has advantages and disadvantages. The physicochemical methods are common methods used in wastewater treatment, such as adsorption and coagulation. Adsorption and coagulation are excellent methods to remove pollutants. The adsorption process is greatly influenced by $\mathrm{pH}$, adsorbent dose, temperature, and contact time. Coagulant dose, settling time, and $\mathrm{pH}$ are the main factors in the coagulation process. Chemical material as an adsorbent and coagulant has been studied in previous research, but recently, to substitution chemical materials is a challenging subject. Natural substances are potential new materials in wastewater treatment and became popular due to their efficiency and environment friendly characteristics. This review investigated the role of adsorption and coagulation in wastewater treatment and the utilization of natural materials as adsorbents and coagulants.
\end{abstract}

\section{KEYWORDS}

adsorption, coagulation, natural adsorbents, natural coagulants, wastewater treatment

*Corresponding author. E-mail: sukmanahadid@gmail.com 


\section{INTRODUCTION}

Water is an essential factor for all life and human survival and has an important role in the drinking water supply and economic sectors (Tiri et al., 2018). The need for water in household and industrial activities is still increasing every year. Nowadays, the world faces a water crisis due to industrial globalization, increasing residential and commercial areas, and agricultural lands that lead to enormous wastewater production (Abdelbasir and Shalan, 2019).

According to global trends, in high-income countries, municipal and industrial wastewater treatment is about $70 \%$, the percentages drop to 38 and $28 \%$ in upper-middle-income and lower-middle-income countries, respectively. Besides, in low-income countries, only $8 \%$ undergoes treatment of any kind, and over $80 \%$ of all wastewater is discharged without treatment (WWAP (United Nations World Water Assessment Programme), 2017). Wastewater treatment is an essential factor in industrial processes because wastewater containing hazardous pollutants has negatively affected all environmental elements, such as air, soil, and water (Mohd Udaiyappan et al., 2017).

The presence of non-biodegradable organic compounds in wastewater, even in small amounts, causes severe public health problems due to endocrine-disrupting, toxic to living organisms, and potential carcinogens (Malik et al., 2020). For example, the industrial process, such as palm oil, olive oil, sunflower oil production, etc., generates many oily contents to wastewater, forming pollution. Oily content is a harmful waste that is discharged into the environment. The concentration and physical nature of the oily content and the droplet sizes affect the removal of oily content in wastewater (Coca-Prados and Gutiérrez-Cervelló, 2010).

In general, the wastewater treatment methods are biological, chemical, physical, and the combination of each method (Kontos et al., 2014). The essential process of wastewater treatment are divided into five steps such as 1) pre-treatment using physicochemical and mechanical methods; 2) primary treatment using physicochemical and chemical methods; 3) secondary treatment using physicochemical and biological methods; 4) tertiary treatment or final treatment using physical and chemical methods; and finally, 5) sludge treatment (Crini and Lichtfouse, 2019). For instance, wastewater treatment technologies include biological techniques, photocatalysis, membrane technology, ultrasonication, adsorption, and coagulation/flocculation. The advantages and disadvantages of technologies of wastewater treatment are shown in Table 1.

Efficient wastewater treatment is the basic need of the present society. The application of wastewater treatment could be a solution for protecting the environment. Adsorption and coagulation are wastewater effective treatment methods with a simple design and lower processing cost used by industry (Cai et al., 2019; dos Santos et al., 2018).

Today, research about adsorption and coagulation for wastewater treatment is still under development. In addition to using chemical adsorbents and coagulants, researchers continue to develop alternative raw materials appropriate for use in the future. Hence, one of the most exciting research objectives is to find out new materials for wastewater treatment. The development of the world that leads to environmentally friendly materials has also encouraged increased research of natural adsorbents and coagulants.

Natural materials could be a potential resource for wastewater treatment that is low-cost, efficient, and environmentally friendly. Therefore, natural adsorbents and coagulants would be alternative solutions for the mitigation of pollution. This review presents and discusses recent information concerning the role of adsorption and coagulation methods in wastewater 
Table 1. Technologies of wastewater treatment

\begin{tabular}{|c|c|c|c|}
\hline $\begin{array}{l}\text { Type of } \\
\text { treatment }\end{array}$ & Advantages & Disadvantages & References \\
\hline Biological & $\begin{array}{l}\text { potential for removing } \\
\text { metals }\end{array}$ & $\begin{array}{c}\text { technology is still under } \\
\text { development }\end{array}$ & (Ahmaruzzaman, 2009) \\
\hline Photocatalysis & high degradation rate & $\begin{array}{l}\text { potential to harmful due to } \\
\text { exposure to carcinogenic } \\
\text { UV light }\end{array}$ & (Cheng et al., 2019) \\
\hline $\begin{array}{l}\text { Membrane } \\
\text { technology }\end{array}$ & $\begin{array}{c}\text { membrane properties could } \\
\text { be adjusted } \\
\text { small occupation area } \\
\text { high processing efficiency }\end{array}$ & membrane fouling & $\begin{array}{l}\text { (Saleh and Gupta, 2016; } \\
\text { Zhang et al., 2016) }\end{array}$ \\
\hline Ultrasonication & $\begin{array}{l}\text { compact } \\
\text { environmentally friendly }\end{array}$ & require high energy & $\begin{array}{c}\text { (Budiman and Wu, 2016; } \\
\text { Mahvi, 2009) }\end{array}$ \\
\hline Adsorption & $\begin{array}{l}\text { simple design } \\
\text { cost-effectiveness } \\
\text { excellent approach for } \\
\text { removing organic } \\
\text { pollutants }\end{array}$ & $\begin{array}{l}\text { require regeneration of the } \\
\text { adsorbent }\end{array}$ & $\begin{array}{c}\text { (Ariffin et al., 2017; } \\
\text { Bazrafshan et al., 2016; } \\
\text { Cai et al., 2019; Diaz de } \\
\text { Tuesta et al., 2018) }\end{array}$ \\
\hline $\begin{array}{l}\text { Coagulation/ } \\
\text { flocculation }\end{array}$ & $\begin{array}{l}\text { simple process } \\
\text { good for reclamation or } \\
\text { removed pollutants }\end{array}$ & $\begin{array}{l}\text { require high dosage } \\
\text { produce massive sludge } \\
\text { and large particles }\end{array}$ & $\begin{array}{l}\text { (Ang and Mohammad, } \\
\text { 2020; Ariffin et al., 2017; } \\
\text { Chethana et al., 2016) }\end{array}$ \\
\hline
\end{tabular}

treatment. This review also compared the removal effectiveness of different natural adsorbents and coagulants as potential materials in the future.

\section{ADSORPTION}

Adsorption is a change in concentration of a given substance at the interface compared with the neighboring phases (Dąbrowski, 2001). Adsorption can occur in the following systems: solidliquid, solid-gas, liquid-gas, and liquid-liquid.

Nowadays, adsorption is one of the most common methods used in industrial wastewater treatment. For instance, adsorption could be used to remove and recover heavy metals in wastewater, even at a low concentration. Therefore, adsorption is a practical and simple process to apply in wastewater treatment compared with other methods. Adsorption methods have several parameters to determine an effective technique, such as $\mathrm{pH}$, adsorbent dose, temperature, and contact time.

The solution $\mathrm{pH}$ plays an essential role in the adsorption process; determining the initial $\mathrm{pH}$ condition is vital for increasing pollutants' removal effectivity. $\mathrm{pH}$ condition in the solution affects the ability between hydrogen ions in the functional group such as hydroxyl $(\mathrm{OH})$, carboxyl (COOH), amine (NH), and metal ions on the adsorbent surface (Huang and Liu, 2013).

The adsorbent dose is one of the critical parameters in the adsorption method due to the adsorbent capacity's effect on the adsorbate initial concentration and plays an important role in determining the optimum process (Afroze et al., 2016). The increasing adsorbent dose could 
increase removal capacity due to greater surface area and more active adsorption sites (Kumar et al., 2016).

The temperature is one of the parameters that impact the adsorption process due to affecting physicochemical reactions. In endothermic reactions, the increasing temperature would increase the reaction rate, whereas, in exothermic reactions, the increasing temperature would decrease the reaction rate (Xu et al., 2018).

Adsorption capacity could be described by contact time. Therefore, the adsorption process requires a specific time to reach equilibrium, which is the time when the adsorption is completed (Ariffin et al., 2017). In the application of contact time, there is time variation to achieve maximum process, depending on adsorbent material and adsorbate.

\section{Mechanisms of adsorption}

The adsorption method is widely used in wastewater treatment due to effective and efficient factors. During adsorption, several steps occur until the process finishes. The adsorption mechanism is shown in Fig. 1.

The adsorption mechanism follows four steps, i.e. (Sotelo et al., 2013):

1. The solution transfers the contaminant molecules/solute to the boundary layer of the adsorbent.

2. Diffusion occurs from the boundary layer to external surface of the adsorbent.

3. Transport from the external surface to active sites of pores.

4. The adsorption of the sorbate to the solid phase.

Adsorption processes are divided into two types, shows in Fig. 2. Physical adsorption (physisorption) and chemical adsorption (chemisorption) have different processes. The physisorption is responsible for attractive forces in molecules and generally occurs with a relatively low degree of specificity, whereas chemisorption is responsible for the structure of chemical compounds due to the involved electrons exchanges (Rouquerol et al., 2013; Tan and Hameed, 2017).

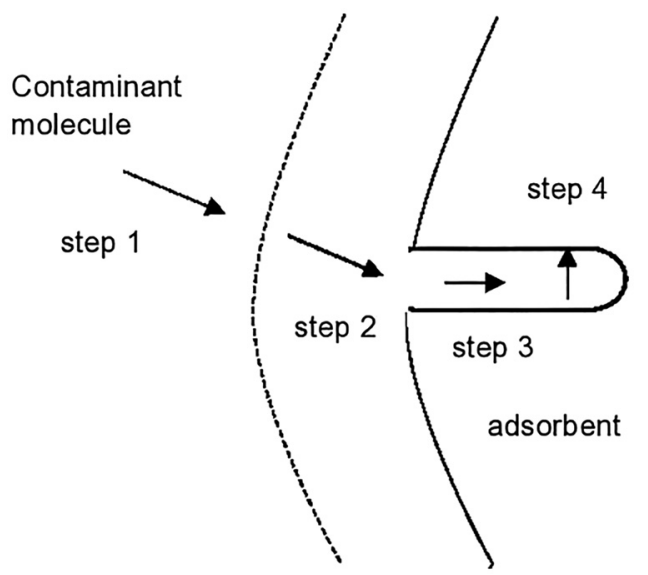

Fig. 1. Adsorption mechanism (Bellahsen et al., 2018) 


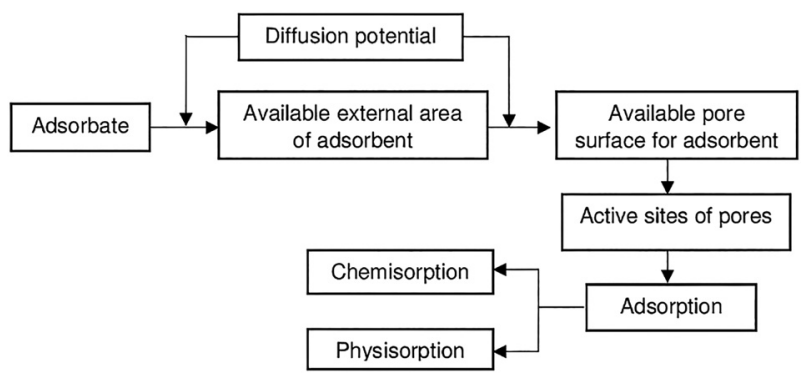

Fig. 2. Pathways of adsorption process (Singh et al., 2018)

\section{Isotherm and kinetics}

The common method for evaluating the adsorption mechanism is adsorption isotherm and kinetics. The adsorption isotherm is described as equilibrium concentration between the solute concentration in the liquid and that on the surface of the adsorbent (Foo and Hameed, 2010). In contrast, adsorption kinetics is described as diffusion behavior and the adsorption rate of solute (Das, 2020). The linear forms of adsorption isotherm and kinetic models are shown in Table 2.

According to Table 2, there are several models in isotherm adsorption. Langmuir isotherm model has two key points in the adsorption process. First, homogeneous adsorption occurs in the adsorbent. Second, adsorbed molecules form a saturated layer on the adsorbent surface so that maximum and monolayer adsorption occurs. The Freundlich isotherm model assumes adsorption capacity has relation to the ion concentration at equilibrium, and adsorption occurs in the heterogeneous surface, also not suitable for low sorbate concentration (Alves et al., 2017; Sadeek et al., 2015).

Dubinin-Redushkevich isotherm model describes the adsorption with a Gaussian energy distribution on a heterogeneous surface. This model could be used to determine the difference in the physical or chemical adsorption process (Üner et al., 2016). Furthermore, the standard model in the kinetic models is pseudo-first-order and pseudo-second-order.

The kinetic model could explain the adsorption process and possible rate-controlling steps, such as chemical reaction processes or mass transport (Anastopoulos et al., 2017). Generally, when adsorption occurs through diffusion through the interface, the kinetic model follows pseudo-first-order. However, pseudo-second-order has a benefit where equilibrium adsorption capacity could be calculated from the model and there is no need to calculate adsorption equilibrium capacity from the experiment (Sarma et al., 2019).

\section{Adsorbent}

The adsorbent is an essential factor in the adsorption process. Adsorbents can capture pollutant substances onto itself, has porosity and is also insoluble in water (Abdi et al., 2017). The utilization of adsorbent usually considers several aspects, such as cost and adsorbent characterization. However, the cost and characteristics of these compounds can influence maximum removal in wastewater.

Firstly, the adsorbent key factor is adsorption capacity, where the adsorbent could adsorb the adsorbate onto its surface. Secondly, excellent adsorbent criteria are short adsorption periods in 
Table 2. The linear forms of adsorption isotherm and kinetic models (Lima et al., 2015; Varala et al., 2019)

\begin{tabular}{|c|c|c|}
\hline Isotherm models & Equation form & Parameters \\
\hline Langmuir & $\frac{1}{q_{e}}=\frac{1}{Q_{0}}+\frac{1}{Q_{0} K_{L} C_{e}}$ & $\begin{array}{l}\mathrm{C}_{\mathrm{e}:} \text { equilibrium concentration of } \\
\quad \text { adsorbate } \\
\mathrm{q}_{\mathrm{e}} \& \mathrm{Q}_{\mathrm{e}} \text { amount of sorbed per } \\
\text { gram of adsorbent } \\
\mathrm{Q}_{0:} \text { maximum monolayer coverage } \\
\text { capacity of sorbent } \\
\mathrm{K}_{\mathrm{L}: \text { Langmuir isotherm constant }} \\
\text { related to the energy of adsorption }\end{array}$ \\
\hline Freundlich & $\log Q_{e}=\log K_{f}+\frac{1}{n} \log C_{e}$ & $\begin{array}{c}\mathrm{K}_{\mathrm{f}} \text { : Freundlich isotherm constant, } \\
\text { an approximate indicator of } \\
\text { adsorption capacity } \\
\mathrm{n} \text { : adsorption intensity/ } \\
\text { heterogeneity parameter }\end{array}$ \\
\hline $\begin{array}{l}\text { Dubinin-Redushkevich } \\
\text { (D-R) }\end{array}$ & $\begin{array}{c}\qquad \ln q_{e}=\ln q_{s}-\left(K_{a d \varepsilon^{2}}\right) \\
\text { where } \varepsilon=R T \ln \left[1+\frac{1}{C_{e}}\right] \text { and } E=\frac{1}{\left(2 K_{a d}\right)^{0.5}}\end{array}$ & $\begin{array}{c}\mathrm{K}_{\mathrm{ad}}: \mathrm{D}-\mathrm{R} \text { isotherm constant } \\
\mathrm{q}_{\mathrm{s}:} \text { theoretical isotherm saturation } \\
\text { capacity }\end{array}$ \\
\hline Sips & $q_{e}=\frac{Q_{0} \cdot K_{s} \cdot C_{e} C_{e} / T_{S}}{1+K_{s} \cdot C_{e}^{1 / n_{S}}}$ where $0<\frac{1}{n_{S}} \leq 1$ & $\begin{array}{c}\mathrm{K}_{\mathrm{s}}: \text { Sips isotherm constant } \\
\mathrm{n}_{\mathrm{S}}: \text { Sips exponent }\end{array}$ \\
\hline Liu & $q_{e}=\frac{Q_{0} \cdot\left(K_{g} \cdot C_{e}\right)^{n_{L}}}{1+\left(K_{g} \cdot C_{e}\right)^{n_{L}}}$ & $\begin{array}{c}\mathrm{K}_{\mathrm{g}}: \text { Liu isotherm constant; } \\
\mathrm{n}_{\mathrm{L}}: \text { Liu exponent }\end{array}$ \\
\hline Redlich-Peterson & $q_{e}=\frac{K_{R P} \cdot C_{e}}{1+a_{R P} \cdot C_{e}^{g}}$ where $0<g \leq 1$ & $\begin{array}{c}\mathrm{K}_{\mathrm{RP}} \text { and } \mathrm{a}_{\mathrm{RP}} \text { : Redlich-Peterson } \\
\text { isotherm constants } \\
\mathrm{g:} \mathrm{Redlich-Peterson} \mathrm{exponent} \\
\text { (dimensionless) whose value } \\
\text { should be } \leq 1\end{array}$ \\
\hline Hill & $q_{e}=\frac{Q_{0} \cdot C_{e}^{n H}}{K H+C_{e}^{n H}}$ & $\begin{array}{c}\text { KH: Hill isotherm constant } \\
\text { nH: Hill exponent (dimensionless) }\end{array}$ \\
\hline Khan & $q_{e}=\frac{Q_{0} \cdot K_{k} \cdot C_{e}}{\left(1+K_{k} \cdot C_{e}\right)^{n_{k}}}$ & $\begin{array}{c}\mathrm{K}_{\mathrm{k}}: \text { Khan isotherm constant } \\
\mathrm{n}_{\mathrm{k}}: \text { Khan exponent (dimensionless) }\end{array}$ \\
\hline Radke-Prausnitz & $q_{e}=\frac{Q_{0} \cdot K_{R A P} \cdot C_{e}}{\left(1+K_{R A P} \cdot C_{e}\right)^{1 / n_{R P}}}$ & $\begin{array}{c}\mathrm{K}_{\mathrm{RAP}}: \text { Radke-Prausnitz isotherm } \\
\text { constant } \\
\mathrm{n}_{\mathrm{RP}}: \text { Radke-Prausnitz exponent } \\
\text { (dimensionless) }\end{array}$ \\
\hline Toth & $q_{e}=\frac{Q_{0} \cdot K_{T} \cdot C_{e}}{\left[1+\left(K_{T} \cdot C_{e}\right)^{1 / n_{T}}\right]^{n_{T}}}$ & $\begin{array}{c}\mathrm{K}_{\mathrm{T}} \text { : Toth isotherm constant } \\
\mathrm{n}_{\mathrm{T}} \text { : Toth exponent (dimensionless) }\end{array}$ \\
\hline
\end{tabular}

\begin{tabular}{|c|c|c|}
\hline Kinetic models & Equation form & Parameters \\
\hline Pseudo-first-order & $\log \left(q_{e}-q_{t}\right)=\log q_{e, m}-\frac{k_{1}}{2.303} t$ & $\begin{array}{c}\mathrm{q}_{\mathrm{t}:} \text { amount of metal sorbed at time } t \\
\mathrm{k}_{1:} \text { the first-order rate constant }\end{array}$ \\
\hline Pseudo-second-order & $\frac{t}{q_{t}}=\frac{1}{k_{2} q_{e, m}^{2}}+\frac{1}{q_{e, m}} t$ & $\mathrm{k}_{2:}$ the second-order rate constant \\
\hline Elovich & $q_{t}=\frac{1}{\beta} \ln (\alpha \cdot \beta)+\frac{1}{\beta} \ln (t)$ & $\begin{array}{c}\alpha \text { : initial adsorption } \\
\beta \text { : related to the extent of surface }\end{array}$ \\
\hline
\end{tabular}

(continued) 
Table 2. Continued

\begin{tabular}{lcc}
\hline Kinetic models & Equation form & Parameters \\
\hline & & coverage and the activation energy \\
involved in chemisorption to: $1 / \alpha \beta$. \\
$\mathrm{k}_{\mathrm{AV}}:$ Avrami kinetic constant \\
Avrami & n: fractional adsorption order \\
\hline
\end{tabular}

the adsorption process (Katheresan et al., 2018). Thirdly, adsorbent with high porosity has a higher surface area with high adsorption capacity (Ballav et al., 2018).

Adsorbents could be classified into two types that are conventional and non-conventional adsorbents. Conventional adsorbents consist of activated carbons, ion-exchange resins (polymeric organic resins), and inorganic materials such as activated alumina, silica gel, zeolites, and molecular sieves. Non-conventional adsorbents consist of industrial/agriculture by-products such as sawdust, bark, solid waste, red mud, etc., and biological by-product such as biomasses, peat, chitosan, other polysaccharides (Crini et al., 2019).

\section{Conventional adsorbent/inorganic adsorbent}

Conventional adsorbents are widely used as commercial adsorbent in the industrial sector or laboratory practice such as activated carbons, zeolites, commercial activated alumina, silica gels, ion-exchange resins. Activated carbons are excellent adsorbents to remove organic pollutants in secondary or tertiary treatment. These materials' benefits are that they do not generate byproducts and could be combined with other techniques such as an ultrafiltration membrane. However, activated carbons are expensive and nonselective. On the other hand, ion-exchange resins could reduce water pollution in the environment. The benefits of this material are no loss of adsorbent on regeneration and reclamation of solvent. Like activated carbons, this material is expensive (Crini et al., 2019).

Several adsorbents from inorganic materials have been studied for removed pollutants in wastewater. The research conducted by Feng et al. (2012) used superparamagnetic ascorbic acidcoated $\mathrm{Fe}_{3} \mathrm{O}_{4}$ nanoparticles to remove arsenic in wastewater. The result shows maximum adsorption capacity for arsenic (V) and arsenic (III) are $16.56 \mathrm{mg} \mathrm{g}^{-1}$ and $46.09 \mathrm{mg} \mathrm{g}^{-1}$, respectively. The Langmuir model was the best model for this study.

The study was carried out by Mahmoud et al. (2016) and used three MgO nanomaterials $\left(\mathrm{MgO}_{\mathrm{S}}, \mathrm{MgO}_{\mathrm{N}}\right.$, and $\left.\mathrm{MgO}_{\mathrm{U}}\right)$ to remove Remazol Red $\mathrm{RB}-133$ in aqueous solution. The result shows the removal efficiency of Remazol Red RB-133 on $\mathrm{MgO}_{S}, \mathrm{MgO}_{\mathrm{N}}$, and $\mathrm{MgO}_{\mathrm{U}}$ was achieved 100,92 , and $76.5 \%$ at $11 \mathrm{~min}$, respectively. Simultaneously, the removal was completed on $\mathrm{MgO}_{\mathrm{N}}$ at $40 \mathrm{~min}$ and $\mathrm{MgO}_{\mathrm{U}}$ at $60 \mathrm{~min}$. The Langmuir and pseudo-first-order models were the best models for this study.

Wang et al. (2019) observed the use of Polyaniline/TiO $2\left(\mathrm{PANI} / \mathrm{TiO}_{2}\right)$ as an adsorbent to remove methylene blue $(\mathrm{MB})$. The result shows that the maximum adsorption capacity was $458.10 \mathrm{mg} \mathrm{g}^{-1}$ with $\mathrm{pH}$ application $(\mathrm{pH} 3-11)$. The regeneration of adsorbent was studied with used $\mathrm{HCl}$ solution $\left(0.1 \mathrm{~mol} \mathrm{~L}^{-1}\right)$ as a stripping agent and, after ten cycles, adsorption efficiency could be maintained around $99 \%$. 


\section{Non-conventional/natural adsorbent}

Natural adsorbent origin is from natural materials or industrial waste/by-products such as agriculture, food, etc. It has a low cost and could be directly used or after minor treatment (Gupta and Suhas, 2009). For instance, agriculture waste is one of the foremost abundant renewable resources globally and available in a considerable amount (Adegoke and Bello, 2015), becoming a source of porous materials rich in active functional groups (da Rocha et al., 2020). Therefore, agriculture waste is a potential material that could be utilized in wastewater treatment.

Currently, the research is focused on developing a natural adsorbent as an alternative for substituting a chemical adsorbent (Martini et al., 2020). The main advantages of natural adsorbents are increased efficiency economically due to low cost and a high removal rate for the highly toxic wastewater (Mathurasa and Damrongsiri, 2018; Mo et al., 2018). However, natural adsorbents also have disadvantages such as the adsorption process running slow and $\mathrm{pH}$ parameter as the main factor to influence the adsorption effect (Mo et al., 2018).

Several natural adsorbents have been studied for pollutants removal from wastewater. For instance, Bellahsen et al. (2021) applied natural adsorbents from the banana peel, compost, bark, wheat husk, wheat bran, sugar beet pulp, and pomegranate peel for the adsorption of ammonium. The result shows pomegranate peel powder (PPP) could achieve $97 \%$ removal, however, other materials showed a negative and low adsorption ability.

Furthermore, Baby et al. (2019) reported the use of agricultural waste palm kernel shell as an adsorbent to remove heavy metals-contaminated water. In this study, heavy metals such as $\mathrm{Pb}^{2+}$, $\mathrm{Cr}^{6+}, \mathrm{Cd}^{2+}$, and $\mathrm{Zn}^{2+}$ could be removed effectively from water. The optimum condition of contact time was $60 \mathrm{~min}$ for $\mathrm{Pb}^{2+}$ and $\mathrm{Cr}^{6+}$ and 90 and $120 \mathrm{~min}$ for $\mathrm{Cd}^{2+}$ and $\mathrm{Zn}^{2+}$, respectively. The percentage of removal obtained was $99 \%$ for $\mathrm{Pb}^{2+}$ and $\mathrm{Cr}^{6+}$, and $\mathrm{Zn}^{2+}$ and $\mathrm{Cd}^{2+}$ was $83 \%$. The adsorption capacity of $\mathrm{Pb}^{2+}$ and $\mathrm{Cr}^{6+}$ was achieved $49.64 \mathrm{mg} \mathrm{g}^{-1}$ and $49.55 \mathrm{mg} \mathrm{g}^{-1}$, respectively, whereas $\mathrm{Cd}^{2+}$ and $\mathrm{Zn}^{2+}$ were achieved $43.12 \mathrm{mg} \mathrm{g}^{-1}$ and $41.72 \mathrm{mg} \mathrm{g}^{-1}$, respectively.

Other than that, Zulkania et al. (2020) found the application of activated carbon and biosorbent produced from palm fibre wastes (PFW) and activated by phosphoric acid. The adsorbent was investigated to remove $\mathrm{MB}$ with the effect of adsorbent type and phosphoric acid concentration. The contact time was found to be $90 \mathrm{~min}$. The result shows optimum adsorption was obtained using activated carbon with $10 \%(\mathrm{v} / \mathrm{v})$ bio-sorbent activating agent concentration and using bio-sorbent with $30 \%(\mathrm{v} / \mathrm{v})$ activating agent concentration. The adsorption capacity and percentage of removal from activated carbon were $9.850 \mathrm{mg} \mathrm{g}^{-1}$ and $98.50 \%$, respectively, while bio-sorbent was achieved $9.984 \mathrm{mg} \mathrm{g}^{-1}$ and $99.84 \%$, respectively.

The modification of rice husk (RH) or rice husk ash (RHA) was investigated by Phan et al. (2019). It used Triamine-activated rice husk ash (TRI-ARHA) as a potential natural adsorbent for nitrate and other anions removal. The TRI-ARHA shows a nitrate adsorption capacity ( $>160$ $\left.\mathrm{mgNO}_{3}{ }^{-} / \mathrm{g}\right)$ compared to the anion exchange resin akulite $\mathrm{A} 420\left(\sim 80 \mathrm{mgNO}_{3}{ }^{-} / \mathrm{g}\right)$, with $10 \mathrm{cycles}$ of adsorption-desorption. Similar results were obtained by Mor et al. (2016) using the activated rice husk ash (ARHA) to remove phosphate in wastewater and water. The ARHA would enhance the adsorption capacity for phosphate with maximum removal of $89 \%$ with $\mathrm{pH} 7,2 \mathrm{~g} \mathrm{~L}^{-1}$ doses, and a time of $120 \mathrm{~min}$. 
Furthermore, the study by Thuy et al. (2020) applied magnesium chloride modified carbonized rice hull (MCRH) to remove ammonium from synthetic and domestic wastewaters. During the $27 \mathrm{~h}$ long treatment, MCRH with $1.8 \mathrm{~g} \mathrm{~L}^{-1}$ concentration could remove $90.7 \%$ ammonium (capacity of $41.0 \mathrm{mg} \mathrm{g}^{-1}$ ) for $81.3 \mathrm{mg} \mathrm{L}^{-1}$ synthetic wastewater and $86.8 \%$ for real domestic wastewater. The Langmuir model was the best model for this study, and based on the Dubinin-Radushkevich model, ammonium was physically adsorbed on MCRH.

Quansah et al. (2020) used rice husk utilization for removing methylene blue (MB) and crystal violet $(\mathrm{CV})$. The rice husk used varying dosage in the range of $0.05-1.0 \mathrm{~g}$ with the initial concentration of $300 \mathrm{mg} \mathrm{L}^{-1}(\mathrm{MB})$ and $400 \mathrm{mg} \mathrm{L}^{-1}(\mathrm{CV})$. The result shows the optimum temperature at $75^{\circ} \mathrm{C}$ with removal percentage of $\mathrm{MB}$ and $\mathrm{CV}$ from $53.74-97.74 \%$ and 57.40 $98.19 \%$, respectively. Mitra et al. (2019) showed that the addition of rice husk as an adsorbent in continuous column mode for the removal of $\mathrm{Pb}$ (II) and $\mathrm{Cr}$ (VI) ions with $\mathrm{pH} 2-6$. The result shows increasing influent concentration $\left(10-30 \mathrm{mg} \mathrm{L}^{-1}\right)$ and indicates the increased capacity of adsorbent for $\mathrm{Pb}$ (II) and $\mathrm{Cr}$ (VI) from 5.72 to $22.99 \mathrm{mg} \mathrm{L}^{-1}$ and $2.798-10.18 \mathrm{mg} \mathrm{L}^{-1}$, respectively. According to the result, statistical analysis showed the Thomas model and the Yoon-Nelson model.

\section{COAGULATION}

The coagulation process has an essential function in wastewater treatment for reclamation or removal of pollutants (Ang and Mohammad, 2020). The coagulation-flocculation process is the major physicochemical treatment method used in industrial wastewater treatment to reduce colloidal turbidity and suspended solids (Gautam and Saini, 2020). According to previous studies, $40 \%$ of organic materials and nitrogen could be removed from wastewater using the coagulation method (Loloei et al., 2014).

Coagulation is a process where the pollutants, suspended particles lead to the sediment through collision with opposite particles and obtain agglomerate to form an insoluble agglomerate complex (Syam Babu et al., 2020). In several types of research, a coagulant dosage, settling time, and $\mathrm{pH}$ are the main factors determining the removal of the contaminant in wastewater. These factors will lead to the optimum conditions in the JAR test. The factor affecting coagulation shows in Table 3 .

\section{Mechanisms of coagulation}

In general, there are four steps in the coagulation/flocculation mechanism, including charge neutralization, sweep coagulation, bridging, and patch flocculation (Amran et al., 2018). The coagulation/flocculation mechanism is shown in Fig. 3.

There are colloidal particles in the coagulation process that are negatively charged, which causes repulsion to occur. The coagulant is added to stabilize the colloid particles so that there is no repulsive force. Usually, the added coagulant is a poly-electrolyte that causes the zeta potential of the colloid close to zero points. Therefore, this process is called the charge neutralization mechanism (Amran et al., 2018). Furthermore, a high concentration of metal salts is added to the water causing the precipitation of amorphous metal hydroxides, and gradually large lumps are formed; this process is called sweep coagulation (Li et al., 2006; Zhao et al., 2011). 
Table 3. Factors affecting coagulation (Kumar et al., 2017)

\begin{tabular}{lll}
\hline Coagulation application & Effective characteristics & \multicolumn{1}{c}{ Properties of natural water } \\
\hline a) Extraction of coagulants & a) Settling time & a) $\mathrm{pH}$ \\
b) Solubility of coagulants & b) Turbulence & b) Alkalinity \\
c) Dosage of coagulants & 1. Rapid Mixing & c) Availability of bacteria \\
d) Charge of particles & 2. Slow Mixing & d) Dissolved Oxygen \\
e) Basicity of a coagulant & c) Coagulant adds & e) Temperature \\
& d) Puantity & f) The element contains (Cl, Na, \\
& & g) Suspended solids
\end{tabular}

The bridging flocculation process could produce a very large floc due to the adsorption of high molecular weight linear-chain compounds commonly based on polyacrylamide. This process occurs at the same time in several particles (Hogg, 2013). Meanwhile, the patch flocculation process occurs because of the adsorption of the polymer onto the particles, thereby a local charge reversal is effected. The result of this process is an attraction force between each particle (Hjorth and Jørgensen, 2012).

\section{Coagulant}

Coagulants could be classified into two types, i.e. chemical and natural coagulants. Both coagulants aim to remove pollutants in the chemical (BOD \& COD) or physical (suspended solids \& turbidity) forms (Kumar et al., 2017). Chemical coagulant includes hydrolyzing metallic salts such as ferric chloride, ferric sulphate, magnesium chloride, and alum; pre-hydrolyzing metallic salts such as poly aluminum chloride (PAC), poly ferric chloride (PFC), poly ferrous sulphate (PFS), poly aluminum ferric chloride, and synthetic cationic polymers such as aminomethyl polyacrylamide, polyalkylene, polyethylenimine, polyamine. Natural coagulant contains microorganism substance such as bacterial, microalgae, fungal; animal-based such as chitosan and isinglass and plant-based such as seed and plant extracts, starch and fruit waste (Al-Sahari et al., 2020; Pandey et al., 2020).

Generally, coagulants are polymers or polyelectrolytes that are synthetic organic compounds with a high molecular weight that make flocs stronger, bigger, and easily settling. Good coagulants could form multi-charged polynuclear complexes in solution with enhanced adsorption characteristics (Iwuozor, 2019).

Several coagulants from chemical materials have been studied for removing pollutants in wastewater. Dhanjal et al. (2018) analyzed the use of alum, potash alum, and poly aluminum chloride for pre-treatment of municipal wastewater. The result shows the most effective coagulant is poly aluminum chloride. The optimum dosage of $500 \mathrm{mg} \mathrm{L}^{-1}$ to remove $\mathrm{pH}$, EC, TDS, TSS, and turbidity were $7.16,700.3 \mu \mathrm{sm}^{-1}, 973 \mathrm{mg} \mathrm{L}^{-1}, 715 \mathrm{mg} \mathrm{L}^{-1}$, and $4.5 \mathrm{NTU}$, respectively. 


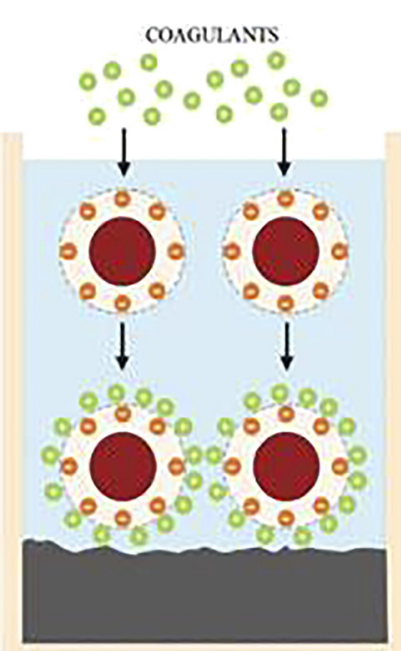

Charge Neutralization

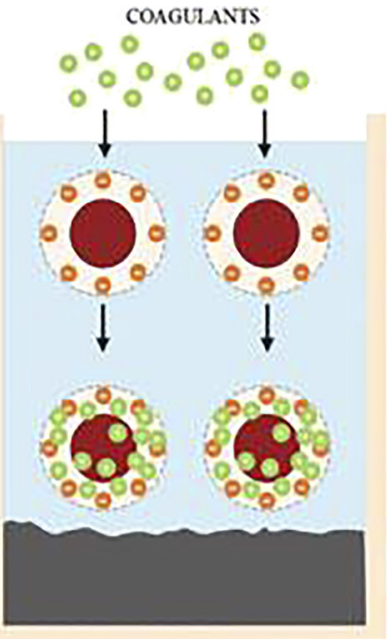

Sweep Coagulation

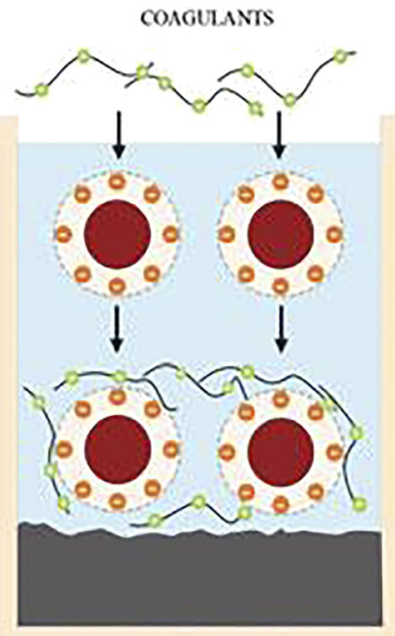

Bridging

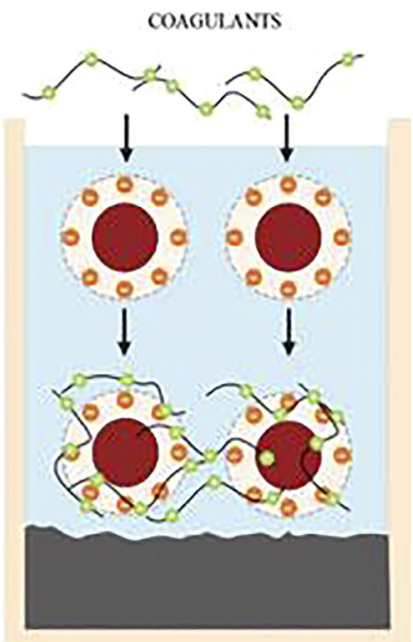

Patch Flocculation

Fig. 3. Coagulation/flocculation mechanisms at the treatment process (Al-Sahari et al., 2020) 
The study was investigated by Zahrim et al. (2017), which used several chemical coagulants such as calcium lactate, ferric chloride, magnesium hydroxide, poly diallyl dimethyl ammonium chloride (polyDADMAC), and aluminum chlorohydrate to remove color in palm oil mill biogas plant wastewater (POMBPW). The result shows ferric chloride is the best coagulant to remove color. Ferric chloride could remove color up to $80 \%$ with an optimum dosage of $8,000 \mathrm{mg} \mathrm{L}^{-1}$ and $\mathrm{pH} 10$.

Furthermore, the research was carried out by Li et al. (2016) used magnesium hydroxide as a chemical coagulant for dyes wastewater treatment. The different dosages and initial turbidity used to determine the optimum condition in coagulation. The result shows optimum dosage, initial turbidity and $\mathrm{pH}$ was achieved $144 \mathrm{mg} \mathrm{L}^{-1}, 45 \mathrm{NTU}$, and 12, respectively. Besides, coagulant dosage increases have an effect of decreasing final turbidity.

\section{Natural coagulant}

Natural coagulant is produced from other natural sources, which have a functional group. For instance, agriculture waste has properties that provide excellent coagulation ability due to the presence of carboxyl and silanol groups (Ahmaruzzaman and Gupta, 2011). Natural coagulant is an environmentally friendly green product, unlike chemical coagulants that could affect human health and the environment (Othmani et al., 2020).

The utilization of natural coagulants in the researches shows an essential improvement to nature and the ecosystem due to biodegradable components. Besides, the utilization of natural coagulants is growing rapidly over the years due to the low impact on $\mathrm{pH}$ and fast reaction. In contrast, a disadvantage of natural coagulants from plant-based is the price so that their use on an industrial scale compared to synthetic coagulants is ineffective. The utilization of these coagulants more effectively removes low-medium turbidity in wastewater treatment (Litu et al., 2019; Nath et al., 2020).

Besides, natural coagulants have been studied in some previous research, such as rice husk ash, Moringa oleifera, Trigonella foenum-graecum, and Hibiscus esculentus, Cassia obtusifolia, and papaya seed powder.

\section{Rice husk ash}

The previous research on RH and RHA for natural coagulants is still limited. For instance, Huzir et al. (2019) investigated the application of RHA as a potential natural coagulant for palm oil mill effluent (POME) treatment with optimum conditions was $\mathrm{pH} 3.6,6.0 \mathrm{~g}$ with a time of 57 min. The results show RHA could remove the total suspended solids (TSS) and chemical oxygen demand (COD) up to 83.88 and $52.38 \%$, respectively.

\section{Moringa oleifera}

Jagaba et al. (2020) observed that the use of M. oleifera as a natural coagulant to compare with a chemical coagulant. The result shows the optimum dosage of $M$. oleifera obtained 2,000 mg L for removing turbidity, oil \& grease, TSS, COD, Color, and $\mathrm{NH}_{3}-\mathrm{N}$. Ahmad et al. (2015) reported the pre-treatment for POME using $M$. oleifera and chitosan as a natural coagulant combined with the integrated membrane. The result shows the percentage of recovery for turbidity value $20 \mathrm{NTU}$ at $78 \%$. Furthermore, a similar result was obtained by Nikam et al. (2012) shows the effectivity of $M$. oleifera as a natural coagulant for reducing turbidity in 
wastewater. The removal percentage of turbidity obtained at $32.52 \%$ with an optimum dosage of $10 \mathrm{mg} \mathrm{L}^{-1}$.

Adelodun et al. (2020) used M. oleifera to remove turbidity, COD, and biochemical oxygen demand (BOD) in municipal wastewater. The result shows the percentage of removal turbidity, COD and BOD were $94.44,57.61$, and $68.72 \%$, respectively, with the optimum dosage of $150 \mathrm{mg} \mathrm{L}^{-1}$ and settling period of $250 \mathrm{~min}$. Also, Muruganandam et al. (2017) reported the pre-treatment for tannery effluent using $M$. oleifera, Cactus, and Aloe vera as a natural coagulant. The result shows the percentage of recovery for turbidity with $M$. oleifera, Cactus, and Aloe vera achieved 59.43, 51.50, $46.76 \%$, respectively then for COD achieved $37.82,59.35,52.60 \%$, respectively. The optimum dosage and $\mathrm{pH}$ condition for $M$. oleifera, are $15 \mathrm{~g} \mathrm{~m}^{-1}$ with $\mathrm{pH}$ 6, for Cactus $40 \mathrm{~g} \mathrm{~mL}^{-1}$ with $\mathrm{pH} 7$ and for Aloe vera $5 \% \mathrm{v} / \mathrm{v}$ with $\mathrm{pH} 5$.

\section{Trigonella foenum-graecum and Okra}

Sui Kim et al. (2020) applied T. foenum-graecum (fenugreek) as a natural coagulant and Hibiscus esculentus (okra) as a natural flocculant for the treatment of POME. The optimum conditions of removal percentages for TSS, COD, and turbidity were found in a dosage of fenugreek is $4.6 \mathrm{~g} \mathrm{~L}^{-1}$, a dosage of okra is $40 \mathrm{~mL} / 500 \mathrm{~mL}$ POME, $\mathrm{pH}$ 4, and speed of mixing is $155 \mathrm{rpm}$. The results from fourier transform infrared (FTIR) spectroscopy show fenugreek and okra have properties that provide excellent coagulation-flocculation ability due to the presence of polysaccharides groups.

In addition, Freitas et al. (2015) studied the combination and inorganic coagulant $\left(\mathrm{FeCl}_{3} 6 \mathrm{H}_{2} \mathrm{O}\right)$ and Okra mucilage as natural coagulant removal of turbidity, COD, and color. The result shows it used an inorganic dosage of $88.0 \mathrm{mg} \mathrm{L}^{-1} \mathrm{Fe}^{3+}$ and okra mucilage dosage $3.20 \mathrm{mg} \mathrm{L}^{-1}$ with $\mathrm{pH} 6$ could remove turbidity, COD, and the color were 97.24, 85.69, and 93.57\%, respectively.

\section{Cassia obtusifolia and papaya seed powder}

Shak and $\mathrm{Wu}$ (2015) analyzed the addition of C. obtusifolia seed gum as a natural coagulant with alum application for treatment of POME. The optimum conditions using response surface methodology (RSM) were found in a dosage of alum of $1.15 \mathrm{~g} \mathrm{~L}^{-1}$, a dosage of C. obtusifolia seed gum is $2.47 \mathrm{~g} \mathrm{~L}^{-1}$, and a settling time of $35.16 \mathrm{~min}$. The removal percentages for COD and TSS were up to 48.22 and $81.58 \%$, respectively. Kristianto et al. (2018) studied the use of papaya seed powder to remove color in synthetic textile wastewater. The result shows the percentage of removal of $84.77 \%$ with optimum conditions were found in coagulant dosage is $0.57 \mathrm{~g} \mathrm{~L}^{-1}$, and $\mathrm{pH} 1.97$.

\section{CONCLUSIONS}

There are several methods to remove pollutants in wastewater treatment. Adsorption and coagulation are the most common methods used; they are simple to use and have more advantages, such as low cost, practice, and efficiency. Therefore, these methods are effective in removing pollutants and obtaining the quality of wastewater according to standards. On the other side, the development of these methods also was followed by new researches about 
materials in adsorption and coagulation from natural resources. One of the sources which was used as a material for adsorbent and coagulant is agriculture waste. Natural materials became a potential opportunity due to their availability in a considerable amount. The utilization of natural adsorbents and coagulants, which are environmentally friendly, could reduce the negative effect on the environment and human health. Previous studies showed that natural adsorbents and coagulants are useful for removing pollutants in wastewater. Therefore, modification of natural adsorbents and coagulants can further be explored for enhanced stability and effectiveness in all wastewater types. Besides, recovery and reuse of natural adsorbents and coagulants have to be continuously developed to ensure environmental sustainability. Finally, applying natural adsorbents and coagulants on the industrial scale requires further investigation as a strategy that will fulfill the goal of the circular economy.

\section{REFERENCES}

Abdelbasir, S.M. and Shalan, A.E. (2019). An overview of nanomaterials for industrial wastewater treatment. Korean Journal of Chemical Engineering, 36(8): 1209-1225.

Abdi, J., Vossoughi, M., Mahmoodi, N.M., and Alemzadeh, I. (2017). Synthesis of metal-organic framework hybrid nanocomposites based on GO and CNT with high adsorption capacity for dye removal. Chemical Engineering Journal, 326: 1145-1158. https://doi.org/10.1016/j.cej.2017.06.054.

Adegoke, K.A. and Bello, O.S. (2015). Dye sequestration using agricultural wastes as adsorbents. Water Resources and Industry, 12: 8-24. https://doi.org/10.1016/j.wri.2015.09.002.

Adelodun, B., Ogunshina, M.S., Ajibade, F.O., Abdulkadir, T.S., Bakare, H.O., and Choi, K.S. (2020). Kinetic and Prediction modeling studies of organic pollutants removal from municipal wastewater using Moringa oleifera biomass as a coagulant. Water, 12(7): 2052. https://doi.org/10.3390/w12072052.

Afroze, S., Sen, T.K., and Ang, H.M. (2016). Adsorption removal of zinc (II) from aqueous phase by raw and base modified Eucalyptus sheathiana bark: kinetics, mechanism and equilibrium study. Process Safety and Environmental Protection, 102: 336-352. https://doi.org/10.1016/j.psep.2016.04.009.

Ahmad, A.L., Idris, I., Chan, C.Y., and Ismail, S. (2015). Reclamation from palm oil mill effluent using an integrated zero discharge membrane-based process. Polish Journal of Chemical Technology, 17(4): 4955. https://doi.org/10.1515/pjct-2015-0068.

Ahmaruzzaman, M. (2009). Role of fly ash in the removal of organic pollutants from wastewater. Energy \& Fuels, 23(3): 1494-1511. https://doi.org/10.1021/ef8002697.

Ahmaruzzaman, M. and Gupta, V.K. (2011). Rice husk and its ash as low-cost adsorbents in water and wastewater treatment. Industrial \& Engineering Chemistry Research, 50(24): 13589-13613. https://doi. org/10.1021/ie201477c.

Al-Sahari, M., Al-Gheethi, A.A.S., and Radin Mohamed, R.M.S. (2020). Natural coagulates for wastewater treatment; A review for application and mechanism. In Prospects of fresh market wastes management in developing countries. Springer, pp. 17-31. https://doi.org/10.1007/978-3-030-42641-5_2.

Alves, M.D., Aracri, F.M., Cren, É.C., and Mendes, A.A. (2017). Isotherm, kinetic, mechanism and thermodynamic studies of adsorption of a microbial lipase on a mesoporous and hydrophobic resin. Chemical Engineering Journal, 311: 1-12. https://doi.org/10.1016/j.cej.2016.11.069.

Amran, A.H., Zaidi, N.S., Muda, K., and Loan, L.W. (2018). Effectiveness of natural coagulant in coagulation process: a review. International Journal of Engineering \& Technology, 7(3.9): 34-37. 
Anastopoulos, I., Karamesouti, M., Mitropoulos, A.C., and Kyzas, G.Z. (2017). A review for coffee adsorbents. Journal of Molecular Liquids, 229: 555-565. https://doi.org/10.1016/j.molliq.2016.12.096.

Ang, W.L. and Mohammad, A.W. (2020). State of the art and sustainability of natural coagulants in water and wastewater treatment. Journal of Cleaner Production, 262: 121267. https://doi.org/10.1016/j.jclepro. 2020.121267.

Ariffin, N., Abdullah, M.M.A.B., Mohd Arif Zainol, M.R.R., Murshed, M.F., Hariz-Zain, Faris, M.A., and Bayuaji, R. (2017). Review on adsorption of heavy metal in wastewater by using geopolymer. MATEC Web of Conferences, 97: 01023. https://doi.org/10.1051/matecconf/20179701023.

Baby, R., Saifullah, B., and Hussein, M.Z. (2019). Palm Kernel Shell as an effective adsorbent for the treatment of heavy metal contaminated water. Scientific Reports, 9(1): 18955. https://doi.org/10.1038/ s41598-019-55099-6.

Ballav, N., Das, R., Giri, S., Muliwa, A.M., Pillay, K., and Maity, A. (2018). 1-cysteine doped polypyrrole (PPy@L-Cyst): a super adsorbent for the rapid removal of $\mathrm{Hg}+2$ and efficient catalytic activity of the spent adsorbent for reuse. Chemical Engineering Journal, 345: 621-630. https://doi.org/10.1016/j.cej. 2018.01.093.

Bazrafshan, E., Amirian, P., Mahvi, A.H., and Ansari-Moghaddam, A. (2016). Application of adsorption process for phenolic compounds removal from aqueous environments: a systematic review. Global NEST Journal, 18(1): 146-163.

Bellahsen, N., Kertész, S., Pásztory, Z., and Hodúr, C. (2018). Adsorption of nutrients using low-cost adsorbents from agricultural waste and by-products - review. Progress in Agricultural Engineering Sciences, 14(1): 1-30. https://doi.org/10.1556/446.14.2018.1.1.

Bellahsen, N, Varga, G., Halyag, N., Kertész, S., Tombácz, E., and Hodúr, C. (2021). Pomegranate peel as a new low-cost adsorbent for ammonium removal. International Journal of Environmental Science and Technology, 18(3): 711-722. https://doi.org/10.1007/s13762-020-02863-1.

Budiman, P.M. and Wu, T.Y. (2016). Ultrasonication pre-treatment of combined effluents from palm oil, pulp and paper mills for improving photofermentative biohydrogen production. Energy Conversion and Management, 119: 142-150. https://doi.org/10.1016/j.enconman.2016.03.060.

Cai, L., Zhang, Y., Zhou, Y., Zhang, X., Ji, L., Song, W., Zhang, H., and Liu, J. (2019). Effective adsorption of diesel oil by crab-shell-derived biochar nanomaterials. Materials, 12(2): 236. https://doi.org/10.3390/ ma12020236.

Cheng, Y.W., Khan, M.R., Ng, K.H., Wongsakulphasatch, S., and Cheng, C.K. (2019). Harnessing renewable hydrogen-rich syngas from valorization of palm oil mill effluent (POME) using steam reforming technique. Renewable Energy, 138: 1114-1126. https://doi.org/10.1016/j.renene.2019.02.040.

Chethana, M., Sorokhaibam, L.G., Bhandari, V.M., Raja, S., and Ranade, V.V. (2016). Green approach to dye wastewater treatment using biocoagulants. ACS Sustainable Chemistry \& Engineering, 4(5): 24952507. https://doi.org/10.1021/acssuschemeng.5b01553.

Coca-Prados, J. and Gutiérrez-Cervelló, G. (2010). Water purification and management. In: José CocaPrados, G.G.-C. (Ed.), Illustrate. Springer.

Crini, G. and Lichtfouse, E. (2019). Advantages and disadvantages of techniques used for wastewater treatment. Environmental Chemistry Letters, 17(1): 145-155. https://doi.org/10.1007/s10311-018-0785-9.

Crini, G., Lichtfouse, E., Wilson, L.D., and Morin-Crini, N. (2019). Conventional and non-conventional adsorbents for wastewater treatment. Environmental Chemistry Letters, 17(1): 195-213. https://doi.org/ 10.1007/s10311-018-0786-8.

da Rocha, H.D., Reis, E.S., Ratkovski, G.P., da Silva, R.J., Gorza, F.D.S., Pedro, G.C., and de Melo, C.P. (2020). Use of PMMA/(rice husk ash)/polypyrrole membranes for the removal of dyes and heavy metal 
ions. Journal of the Taiwan Institute of Chemical Engineers, 110: 8-20. https://doi.org/10.1016/j.jtice. 2020.03.003.

Dąbrowski, A. (2001). Adsorption - from theory to practice. Advances in Colloid and Interface Science, 93(1-3): 135-224. https://doi.org/10.1016/S0001-8686(00)00082-8.

Das, A.B. (2020). Separation, purification and application bioactive compounds from pigmented rice bran. Department of Chemical Engineering, Indian Institute of Technology Guwahati. http://gyan.iitg.ernet. in/handle/123456789/1787.

Dhanjal, D.S., Singh, S., Bhatia, D., Singh, J., Sharma, N.R., and Kanwar, R.S. (2018). Pre-treatment of the municipal wastewater with chemical coagulants. Pollut Res, 37: S32-S38. https://www.researchgate.net/ profile/Simranjeet-Singh-4/publication/326145645_PRE-TREATMENT_OF_THE_MUNICIPAL_ WASTEWATER_WITH_CHEMICAL_COAGULANTS/links/5b3aeff30f7e9b0df5e83837/PRETREATMENT-OF-THE-MUNICIPAL-WASTEWATER-WITH-CHEMICAL-COAGULANTS.pdf.

Diaz de Tuesta, J.L., Silva, A.M.T., Faria, J.L., and Gomes, H.T. (2018). Removal of Sudan IV from a simulated biphasic oily wastewater by using lipophilic carbon adsorbents. Chemical Engineering Journal, 347: 963-971. https://doi.org/10.1016/j.cej.2018.04.105.

dos Santos, J.D., Veit, M.T., Juchen, P.T., da Cunha Gonçalves, G., Palácio, S.M., and Fagundes-Klen, M. (2018). Use of different coagulants for cassava processing wastewater treatment. Journal of Environmental Chemical Engineering, 6(2): 1821-1827. https://doi.org/10.1016/j.jece.2018.02.039.

Feng, L., Cao, M., Ma, X., Zhu, Y., and Hu, C. (2012). Superparamagnetic high-surface-area Fe3O4 nanoparticles as adsorbents for arsenic removal. Journal of Hazardous Materials, 217-218: 439-446. https://doi.org/10.1016/j.jhazmat.2012.03.073.

Foo, K.Y. and Hameed, B.H. (2010). Insights into the modeling of adsorption isotherm systems. Chemical Engineering Journal, 156(1): 2-10. https://doi.org/10.1016/j.cej.2009.09.013.

Freitas, T., Oliveira, V.M., de Souza, M.T.F., Geraldino, H.C.L., Almeida, V.C., Fávaro, S.L., and Garcia, J.C. (2015). Optimization of coagulation-flocculation process for treatment of industrial textile wastewater using okra (A. esculentus) mucilage as natural coagulant. Industrial Crops and Products, 76: 538-544. https://doi.org/10.1016/j.indcrop.2015.06.027.

Gautam, S. and Saini, G. (2020). Use of natural coagulants for industrial wastewater treatment. Global Journal of Environmental Science and Management, 6(4). 553-578. https://doi.org/10.22034/GJESM. 2020.04.10.

Gupta, V.K. and Suhas. (2009). Application of low-cost adsorbents for dye removal - a review. Journal of Environmental Management, 90(8): 2313-2342. https://doi.org/10.1016/j.jenvman.2008.11.017.

Hjorth, M. and Jørgensen, B.U. (2012). Polymer flocculation mechanism in animal slurry established by charge neutralization. Water Research, 46(4): 1045-1051. https://doi.org/10.1016/j.watres.2011.11.078.

Hogg, R. (2013). Bridging flocculation by polymers. KONA Powder and Particle Journal, 30: 3-14. https:// doi.org/10.14356/kona.2013005.

Huang, W. and Liu, Z. (2013). Biosorption of $\mathrm{Cd}(\mathrm{II}) / \mathrm{Pb}$ (II) from aqueous solution by biosurfactant-producing bacteria: isotherm kinetic characteristic and mechanism studies. Colloids and Surfaces B: Biointerfaces, 105: 113-119. https://doi.org/10.1016/j.colsurfb.2012.12.040.

Huzir, N.M., Aziz, M.M.A., Ismail, S.B., Mahmood, N.A.N., Umor, N.A., and Faua'ad Syed Muhammad, S.A. (2019). Optimization of coagulation-flocculation process for the palm oil mill effluent treatment by using rice husk ash. Industrial Crops and Products, 139: 111482. https://doi.org/10.1016/j.indcrop.2019. 111482 . 
Iwuozor, K.O. (2019). Prospects and challenges of using coagulation-flocculation method in the treatment of effluents. Advanced Journal of Chemistry-Section A, 2(2): 105-127. https://doi.org/10.29088/SAMI/ AJCA.2019.2.105127.

Jagaba, A.H., Kutty, S.R.M., Hayder, G., Latiff, A.A.A., Aziz, N.A.A., Umaru, I., Ghaleb, A.A.S., Abubakar, S., Lawal, I.M., and Nasara, M.A. (2020). Sustainable use of natural and chemical coagulants for contaminants removal from palm oil mill effluent: a comparative analysis. Ain Shams Engineering Journal, 11(4): 951-960. https://doi.org/10.1016/j.asej.2020.01.018.

Katheresan, V., Kansedo, J., and Lau, S.Y. (2018). Efficiency of various recent wastewater dye removal methods: a review. Journal of Environmental Chemical Engineering, 6(4): 4676-4697. https://doi.org/10. 1016/j.jece.2018.06.060.

Kontos, S.S., Koutsoukos, P.G., and Paraskeva, C.A. (2014). Removal and recovery of phenolic compounds from olive mill wastewater by cooling crystallization. Chemical Engineering Journal, 251: 319-328. https://doi.org/10.1016/j.cej.2014.04.047.

Kristianto, H., Kurniawan, M.A., and Soetedjo, J.N.M. (2018). Utilization of papaya seeds as natural coagulant for synthetic textile coloring agent wastewater treatment. International Journal on Advanced Science, Engineering and Information Technology, 8: 2071-2077. https://core.ac.uk/download/pdf/ 296922219.pdf.

Kumar, V., Othman, N., and Asharuddin, S. (2017). Applications of natural coagulants to treat wastewater - A review. MATEC Web of Conferences, 103: 06016. https://doi.org/10.1051/matecconf/ 201710306016.

Kumar, A., Singha, S., Sengupta, B., Dasgupta, D., Datta, S., and Mandal, T. (2016). Intensive insight into the enhanced utilization of rice husk ash: abatement of rice mill wastewater and recovery of silica as a value added product. Ecological Engineering, 91: 270-281. https://doi.org/10.1016/j.ecoleng.2016.02.034.

Li, H., Liu, S., Zhao, J., and Feng, N. (2016). Removal of reactive dyes from wastewater assisted with kaolin clay by magnesium hydroxide coagulation process. Colloids and Surfaces A: Physicochemical and Engineering Aspects, 494: 222-227. https://doi.org/10.1016/j.colsurfa.2016.01.048.

Li, T., Zhu, Z., Wang, D., Yao, C., and Tang, H. (2006). Characterization of floc size, strength and structure under various coagulation mechanisms. Powder Technology, 168(2): 104-110. https://doi.org/10.1016/j. powtec.2006.07.003.

Lima, É.C., Adebayo, M.A., and Machado, F.M. (2015). Kinetic and equilibrium models of adsorption. In: Carbon nanomaterials as adsorbents for environmental and biological applications. Springer, pp. 33-69.

Litu, L., Ciobanu, G., Cîmpeanu, S.M., Kotova, O., Ciocinta, R., Bucur, D., and Harja, M. (2019). Comparative study between flocculation-coagulation processes in raw/wastewater treatment. The AgroLife Scientific Journal, 8(1): 139-145.

Loloei, M., Nekonam, G., Alidadi, H., and Kor, Y. (2014). Study of the coagulation process in wastewater treatment of dairy industries. International Journal of Environmental Health Engineering, 3(1): 12. https://doi.org/10.4103/2277-9183.132684.

Mahmoud, H.R., Ibrahim, S.M., and El-Molla, S.A. (2016). Textile dye removal from aqueous solutions using cheap $\mathrm{MgO}$ nanomaterials: adsorption kinetics, isotherm studies and thermodynamics. Advanced Powder Technology, 27(1): 223-231. https://doi.org/10.1016/j.apt.2015.12.006.

Mahvi, A.H. (2009). Application of ultrasonic technology for water and wastewater treatment. Iranian Journal of Public Health, 38(2): 1-17.

Malik, S.N., Ghosh, P.C., Vaidya, A.N., and Mudliar, S.N. (2020). Hybrid ozonation process for industrial wastewater treatment: Principles and applications: a review. Journal of Water Process Engineering, 35: 101193. https://doi.org/10.1016/j.jwpe.2020.101193. 
Martini, S., Afroze, S., and Ahmad Roni, K. (2020). Modified eucalyptus bark as a sorbent for simultaneous removal of COD, oil, and Cr(III) from industrial wastewater. Alexandria Engineering Journal, 59(3): 1637-1648. https://doi.org/10.1016/j.aej.2020.04.010.

Mathurasa, L. and Damrongsiri, S. (2018). Low cost and easy rice husk modification to efficiently enhance ammonium and nitrate adsorption. International Journal of Recycling of Organic Waste in Agriculture, 7(2): 143-151. https://doi.org/10.1007/s40093-018-0200-3.

Mitra, T., Bar, N., and Das, S.K. (2019). Rice husk: green adsorbent for $\mathrm{Pb}(\mathrm{II})$ and $\mathrm{Cr}(\mathrm{VI})$ removal from aqueous solution-column study and GA-NN modeling. SN Applied Sciences, 1(5): 486. https://doi.org/ 10.1007/s42452-019-0513-5.

Mo, J., Yang, Q., Zhang, N., Zhang, W., Zheng, Y., and Zhang, Z. (2018). A review on agro-industrial waste (AIW) derived adsorbents for water and wastewater treatment. Journal of Environmental Management, 227: 395-405. https://doi.org/10.1016/j.jenvman.2018.08.069.

Mohd Udaiyappan, A.F., Abu Hasan, H., Takriff, M.S., and Sheikh Abdullah, S.R. (2017). A review of the potentials, challenges and current status of microalgae biomass applications in industrial wastewater treatment. Journal of Water Process Engineering, 20: 8-21. https://doi.org/10.1016/j.jwpe.2017.09.006.

Mor, S., Chhoden, K., and Ravindra, K. (2016). Application of agro-waste rice husk ash for the removal of phosphate from the wastewater. Journal of Cleaner Production, 129: 673-680. https://doi.org/10.1016/j. jclepro.2016.03.088.

Muruganandam, L., Saravana Kumar, M.P., Jena, A., Gulla, S., and Godhwani, B. (2017). Treatment of waste water by coagulation and flocculation using biomaterials. IOP Conference Series: Materials Science and Engineering, 263: 032006. https://doi.org/10.1088/1757-899X/263/3/032006.

Nath, A., Mishra, A., and Pande, P.P. (2020). A review natural polymeric coagulants in wastewater treatment. Materials Today: Proceedings. https://doi.org/10.1016/j.matpr.2020.03.551.

Nikam, S.A., Singh, J.P., Saha, A., and Dubey, A. (2012). Biocoagulant: for waste water treatment. Advances in Computational Sciences and Technology, 5(2): 111-117. https://www.researchgate.net/profile/ Jitendra-Singh-67/publication/325670465_Biocoagulant_For_Waste_Water_Treatment_using moringa_oleifera_seed_and_chitosan_powder/links/5b1cafc9a6fdcca67b682c8b/Biocoagulant-ForWaste-Water-Treatment-using-moringa-oleifer.

Othmani, B., Rasteiro, M.G., and Khadhraoui, M. (2020). Toward green technology: a review on some efficient model plant-based coagulants/flocculants for freshwater and wastewater remediation. Clean Technologies and Environmental Policy, 22(5): 1025-1040. https://doi.org/10.1007/s10098-020-01858-3.

Pandey, P., Khan, F., Mishra, R., and Singh, S.K. (2020). Elucidation of the potential of Moringa oleifera leaves extract as a novel alternate to the chemical coagulant in water treatment process. Water Environment Research, 92(7): 1051-1056. https://doi.org/10.1002/wer.1300.

Phan, P.T., Nguyen, T.T., Nguyen, N.H., and Padungthon, S. (2019). Triamine-bearing activated rice husk ash as an advanced functional material for nitrate removal from aqueous solution. Water Science and Technology, 79(5): 850-856. https://doi.org/10.2166/wst.2018.445.

Quansah, J.O., Hlaing, T., Lyonga, F.N., Kyi, P.P., Hong, S.-H., Lee, C.-G., and Park, S.-J. (2020). Nascent rice husk as an adsorbent for removing cationic dyes from textile wastewater. Applied Sciences, 10(10): 3437. https://doi.org/10.3390/app10103437.

Rouquerol, J., Rouquerol, F., Llewellyn, P., Maurin, G., and Sing, K.S.W. (2013). Adsorption by powders and porous solids: principles, methodology and applications. Academic press.

Sadeek, S.A., Negm, N.A., Hefni, H.H.H., and Wahab, M.M.A. (2015). Metal adsorption by agricultural biosorbents: adsorption isotherm, kinetic and biosorbents chemical structures. International Journal of Biological Macromolecules, 81: 400-409. https://doi.org/10.1016/j.ijbiomac.2015.08.031. 
Saleh, T.A. and Gupta, V.K. (2016). Nanomaterial and polymer membranes: synthesis, characterization, and applications. Elsevier.

Sarma, G.K., Sen Gupta, S., and Bhattacharyya, K.G. (2019). Nanomaterials as versatile adsorbents for heavy metal ions in water: a review. Environmental Science and Pollution Research, 26(7): 6245-6278. https://doi.org/10.1007/s11356-018-04093-y.

Shak, K.P.Y. and Wu, T.Y. (2015). Optimized use of alum together with unmodified Cassia obtusifolia seed gum as a coagulant aid in treatment of palm oil mill effluent under natural $\mathrm{pH}$ of wastewater. Industrial Crops and Products, 76: 1169-1178. https://doi.org/10.1016/j.indcrop.2015.07.072.

Singh, N.B., Nagpal, G., Agrawal, S., and Rachna. (2018). Water purification by using adsorbents: a review. Environmental Technology \& Innovation, 11: 187-240. https://doi.org/10.1016/j.eti.2018.05.006.

Sotelo, J.L., Ovejero, G., Rodríguez, A., Álvarez, S., and García, J. (2013). Study of natural clay adsorbent sepiolite for the removal of caffeine from aqueous solutions: batch and fixed-bed column operation. Water, Air, \& Soil Pollution, 224(3): 1466. https://doi.org/10.1007/s11270-013-1466-8.

Sui Kim, I.T., Sethu, V., Arumugasamy, S.K., and Selvarajoo, A. (2020). Fenugreek seeds and okra for the treatment of palm oil mill effluent (POME) - characterization studies and modeling with backpropagation feedforward neural network (BFNN). Journal of Water Process Engineering, 37: 101500. https://doi.org/10.1016/j.jwpe.2020.101500.

Syam Babu, D., Anantha Singh, T.S., Nidheesh, P.V., and Suresh Kumar, M. (2020). Industrial wastewater treatment by electrocoagulation process. Separation Science and Technology, 55(17): 3195-3227. https:// doi.org/10.1080/01496395.2019.1671866.

Tan, K.L. and Hameed, B.H. (2017). Insight into the adsorption kinetics models for the removal of contaminants from aqueous solutions. Journal of the Taiwan Institute of Chemical Engineers, 74: 25-48. https://doi.org/10.1016/j.jtice.2017.01.024.

Thuy, N.T., Tran Dang Lan, V., Nguyen Xuan, H., Le Thi Bich, S., Tran Thi Ngoc, M., Dang Van, T., and Nguyen Nhat, H. (2020). Study on the removal of ammonia in wastewater using adsorbent prepared from rice hull with magnesium oxide modification. Vietnam Journal of Science and Technology, 58(3A): 113. https://doi.org/10.15625/2525-2518/58/3A/14322.

Tiri, A., Belkhiri, L., and Mouni, L. (2018). Evaluation of surface water quality for drinking purposes using fuzzy inference system. Groundwater for Sustainable Development, 6: 235-244. https://doi.org/10.1016/ j.gsd.2018.01.006.

Üner, O., Geçgel, Ü., and Bayrak, Y. (2016). Adsorption of methylene blue by an efficient activated carbon prepared from citrullus lanatus rind: kinetic, isotherm, thermodynamic, and mechanism analysis. Water, Air, \& Soil Pollution, 227(7): 247. https://doi.org/10.1007/s11270-016-2949-1.

Varala, S., Ravisankar, V., Al-Ali, M., Pownceby, M.I., Parthasarathy, R., and Bhargava, S.K. (2019). Process optimization using response surface methodology for the removal of thorium from aqueous solutions using rice-husk. Chemosphere, 237: 124488. https://doi.org/10.1016/j.chemosphere.2019.124488.

Wang, N., Chen, J., Wang, J., Feng, J., and Yan, W. (2019). Removal of methylene blue by Polyaniline/TiO2 hydrate: adsorption kinetic, isotherm and mechanism studies. Powder Technology, 347: 93-102. https:// doi.org/10.1016/j.powtec.2019.02.049.

WWAP (United Nations World Water Assessment Programme). (2017). The United Nations World Water Development report, 2017. UNESCO.

Xu, J., Cao, Z., Zhang, Y., Yuan, Z., Lou, Z., Xu, X., and Wang, X. (2018). A review of functionalized carbon nanotubes and graphene for heavy metal adsorption from water: preparation, application, and mechanism. Chemosphere, 195: 351-364. https://doi.org/10.1016/j.chemosphere.2017.12.061. 
Zahrim, A.Y., Dexter, Z.D., Joseph, C.G., and Hilal, N. (2017). Effective coagulation-flocculation treatment of highly polluted palm oil mill biogas plant wastewater using dual coagulants: decolourisation, kinetics and phytotoxicity studies. Journal of Water Process Engineering, 16: 258-269. https://doi.org/10.1016/j. jwpe.2017.02.005.

Zhang, F., Gao, S., Zhu, Y., and Jin, J. (2016). Alkaline-induced superhydrophilic/underwater superoleophobic polyacrylonitrile membranes with ultralow oil-adhesion for high-efficient oil/water separation. Journal of Membrane Science, 513: 67-73. https://doi.org/10.1016/j.memsci.2016.04.020.

Zhao, Y.X., Gao, B.Y., Shon, H.K., Wang, Y., Kim, J.-H., and Yue, Q.Y. (2011). The effect of second coagulant dose on the regrowth of flocs formed by charge neutralization and sweep coagulation using titanium tetrachloride (TiCl4). Journal of Hazardous Materials, 198: 70-77. https://doi.org/10.1016/j. jhazmat.2011.10.015.

Zulkania, A., Iqbal, M., and Syamsumarlin. (2020). Characterization of adsorbents derived from palm fiber waste and its potential on methylene blue adsorption. Key Engineering Materials, 841: 273-277. https:// doi.org/10.4028/www.scientific.net/KEM.841.273.

Open Access. This is an open-access article distributed under the terms of the Creative Commons Attribution 4.0 International License (https://creativecommons.org/licenses/by/4.0/), which permits unrestricted use, distribution, and reproduction in any medium, provided the original author and source are credited, a link to the CC License is provided, and changes - if any - are indicated. (SID_1) 